\title{
Biological Control of Tomato Bacterial Wilt Disease by Endophytic Pseudomonas fluorescens and Bacillus subtilis
}

\author{
M.G. Farahat", Tahany, M. Abdel Rahman*, Gihan M. \\ Zaghlol $^{* *}$ and R.A. Hussein* \\ "Botany and Microbiology Department, Faculty of Science, \\ Cairo University, Giza and *Botany and Microbiology \\ Department, Faculty of Science, Helwan University, Cairo, \\ Egypt.
}

\begin{abstract}
R ACTERIAL wilt disease caused by Ralstonia solanacearum is a serious threat for agricultural production of tomato. In this study, 80 endophytic bacterial isolates were isolated from healthy tomato plants in $R$. solanacearum-infested fields. Two endophy tic antagonists designated HRA32 and HRA69 showing the highest antagonistic activity via in vitro screening were identified as Pseudomonas fluorescens and Bacillus subtilis using 16S rRNA analysis. The selected isolates were evaluated in vitro for their activities related to plant nutrition and plant growth regulation. Both of the assessed endophytes were found to exhibit capabilities in ammonia, indole acetic acid (IAA) and siderophore production as well as phosphate solubilization. Pot experiments were adopted to test the control efficiency against tomato bacterial wilt. Results revealed that HRA32 and HRA69 significantly reduced disease incidence when applied as separate treatments. The clear synergetic effect was observed in tomato plants treated with a mixture of the two antagonists reducing disease incidence significantly from $87.22 \%$ in the control to $16.66 \%$ with biological control efficacy of $80.23 \%$. It is concluded that application of $P$. fluorescens HRA32 and $B$. subtilis HRA69 may be a promising approach for biological control of the tomato bacterial wilt and may play an important role in sustainable agriculture.
\end{abstract}

Keywords: Biological control, Bacterial Wilt, Endophyte, Pseudomonas, Bacillus, Ralstonia solanacearum .

In Egypt, tomato (Solanum lycopersicum) is considered one of the most important vegetable crops. The cultivated area is 216,385 ha producing 8,544 , 990 tons with a productivity of $394,898 \mathrm{~kg} / \mathrm{ha}$ (FAO, 2010). Bacterial wilt of tomato caused by Ralstonia solanacearum, causes a considerable amount of damage to tomatoes and many other crops in tropical, subtropical and warm regions of the world and limits the production of many crops e.g. potato, tomato, eggplant and pepper. Approximately 450 plant species have been reported as hosts of this pathogen (Grimault et al., 1994; Williamson et al., 2002; Ji et al., 2005; Swanson et al., 2005; Seleim et al., 2014). During infection, the pathogen can invade plant roots through wounds, and multiply in the cortical tissue before invading the xylem elements. In a matter of hours, the bacteria can spread into 
the crown and stem through the plant's vascular system (Vasse et al., 1995). As the cell concentration number increases, virulence genes are expressed and cells become nonmotile and secrete exopolys accharide and pectin-degrading enzymes, leading to the death of the plant (Saile et al., 1997).

To date, no effective control method has been developed for this wilt disease. Plant breeding, field sanitation, crop rotation, and use of bactericides have met induce with only limited success due to the high variability of the pathogen, high capacity of the pathogen to survive in diverse environments and its extremely wide host range (Lemessa and Zeller, 2007; Nguyen and Ranamukhaarachchi, 2010). Therefore, developing effective biological control agents is very important for the control of tomato bacterial wilt. Biological control not only increases crop yield and suppresses disease but also avoids environmental pollution. Rhizobacteria have been applied to various crops to enhance growth, seed emergence, crop yield and disease control (Wang et al., 2010; Babu et al., 2015 and Mansotra et al., 2015). Plant growth promoting rhizobacteria (PGPR) are a heterogeneous group of bacteria that can be found in the rhizosphere, at root surfaces and in association with roots, which can improve the extent or quality of plant growth directly and/or indirectly.

The mechanisms by which PGPR can influence plant growth may differ from species to species as well as from strain to strain. Growth promotion mechanisms may be direct, i.e., production of growth hormones, phosphate solubilization, nitrogen fixation or indirect, such as suppression of deleterious microorganisms by siderophore production or secretion of antimicrobial metabolites (Jha et al., 2012 and Thokchom et al., 2014). PGPR can protect plants against pathogens by various mechanisms such as antibiosis, nutrient competition or niche exclusion (Lugtenberg and Kamilova, 2009).

The objective of this research was to isolate and evaluate potential edophytic antagonists for their ability to suppress the growth of $R$. solanacearum in vitro and in vivo conditions in attempt to control bacterial wilt disease in tomato.

\section{Material and Methods}

\section{Isolation of Ralstonia solanacearum from diseased plants}

Tomato plants showing bacterial wilt symptoms were collected from local fields in Giza governerate, Egypt and washed under running tap water to remove sand and soil. The stems of the plants were surface sterilized with $70 \%$ alcohol, flamed, chopped using a sterile scalpel and immersed in sterile water to allow the bacteria to ooze out from the infected stem. After $30 \mathrm{~min}$. a loopful of the suspension was streaked onto triphenyl tetrazolium chloride (TTC) agar $(0.5 \%$ glucose, $1.0 \%$ peptone, $0.1 \%$ casamino acid and $1.8 \%$ agar with $5 \mathrm{ml}$ of a $1 \%$ stock solution of 2,3,5-triphenyl tetrazolium chloride) as described by Kelman (1954). After $48 \mathrm{hr}$ incubation at $30^{\circ} \mathrm{C}$, colonies showing irregular viscous appearance with pink centre and white border were selected, purified and tested

Egypt. J. Bot., 56, No. 2 (2016) 
for its solubility in $3 \% \mathrm{KOH}$ to eliminate any possible confusion of the organism with other wilt causing pathogen of tomato (Maji and Chakrabartty, 2014). KOH soluble colony designated TW 15 was selected as a putative $R$. solanacearum.

\section{Pathogen identification by $16 S$ ribosomal RNA}

The isolated phytopathogen was identified by sequencing of 16S rRNA gene.

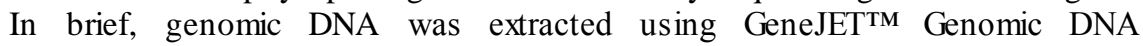
Purification Kit (Thermo Scientific, USA) according to manufacturer's protocol and the 16S rRNA gene was amplified by polymerase chain reaction (PCR) using universal primers 27F (5'-AGAGTTTGATCMTGGCTCAG-3') and 1492R (5'-TACGGYTACCTTGTTACGACTT-3'). PCR was performed in a total volume of $50 \mu \mathrm{l}$ containing $2.5 \mu \mathrm{l} 10 \mathrm{X}$ DreamTaq buffer, $50 \mathrm{ng}$ genomic DNA template, $0.4 \mu \mathrm{M}$ of each primer, $0.2 \mathrm{mM}$ of each dNTP, one unit DreamTaq DNA polymerase (Thermo Scientific, USA) and finally water was added to make volume up to $50 \mu$ l. The amplification reaction was done in GeneAmp 9700 thermal cycler (Applied Biosystems, USA) with the following program: initial denaturation at $94^{\circ} \mathrm{C}$ for $4 \mathrm{~min}$, denaturation at $94^{\circ} \mathrm{C}$ for $40 \mathrm{~s}$, annealing at $55^{\circ} \mathrm{C}$ for $40 \mathrm{~s}$, extension at $72^{\circ} \mathrm{C}$ for $1.5 \mathrm{~min}$ for 30 cycles, and a final extension at $72^{\circ} \mathrm{C}$ for $8 \mathrm{~min}$. The amplified PCR product was purified using the QIAquick PCR Purification kit (Qiagen, Germany) according to the supplier's instructions. The purified DNA was sequenced with $27 \mathrm{~F}$ and $1492 \mathrm{R}$ primers at GATC Biotech (Konstanz, Germany) using ABI 3730xI sequence analyzer (Applied Biosystems, USA). The forward and reverse DNA sequence reads were as sembled to obtain the consensus sequence by using DNA Baser Sequence Assembler software v.3.5.3. Bacterial identification was conducted by comparing the obtained sequence against the BLAST server (http://blast.ncbi.nlm.nih.gov/Blast.cgi) and the EzTaxon-e server database (Kim et al., 2012).

\section{Biovar determination}

Biovar of $R$. solanacearum TW15 was determined according to method described by Hayward (1964) with some modifications. Lactose, maltose, cellobiose, mannitol, sorbitol and dulcitol solutions were filter-sterilized and supplemented to basal medium $\left(\mathrm{NH}_{4} \mathrm{H}_{2} \mathrm{PO}_{4} 1.0 \mathrm{~g}, \mathrm{KCl} 0.2 \mathrm{~g}, \mathrm{MgSO}_{4} .7 \mathrm{H}_{2} \mathrm{O} 0.2 \mathrm{~g}\right.$, Difco bacto peptone $1.0 \mathrm{~g}$, Agar $3.0 \mathrm{~g}$ and Bromothymol blue $80.0 \mathrm{mg}$ per litre). For control glucose water instead of sugar solution was used into the basal medium. $200 \mu \mathrm{l}$ quantities were dispensed into sterile tissue culture plates (96 wells ). $20 \mu \mathrm{l}$ of bacterial suspension $\left(10^{8} \mathrm{CFU} / \mathrm{ml}\right)$ was inoculated into each well containing sugar solutions. The plates were then examined after 3 days of inoculation for changing $\mathrm{pH}$ which was indicated by the change of colour (Schaad, 1988).

Isolation of endophytic bacterial antagonists

Healthy tomato plants were gently uprooted and brought to laboratory. Root sections were made using a sterile scalpel. The root samples of $2-3 \mathrm{~cm}$ long were excised and surface sterilized by sequential immersion in $70 \%$ alcohol for $1 \mathrm{~min}$. $2.5 \%$ sodium hypochlorite for $2 \mathrm{~min}$. and $0.1 \% \mathrm{HgCl}_{2}$ for $1 \mathrm{~min}$. and 
washed in four changes of sterile phosphate buffered saline (PBS). Aliquots from the final buffer wash were checked for sterility. Selected samples were triturated in $10.0 \mathrm{ml}$ of PBS in sterile pestle and mortar. The triturate was serially diluted and used for isolation of potential antagonists to R. solanacearum by modified triple layer agar technique (Herr, 1959).

For preparing the triple layer agar medium, $1 \mathrm{ml}$ triturated root suspension was placed in a Petri dish to which $10 \mathrm{ml}$ of $10 \%$ trypticase soy agar (TSA) (4 g of TSA in 1 liter DW) was added and stirred well. Petri dishes were allowed to stand for $1 \mathrm{hr}$ to for solidification of the medium. A second layer of agar $(5-7 \mathrm{ml}$ of $0.1 \mathrm{~g}$ agar in $100 \mathrm{ml}$ DW) was then poured on top of the first layer. Plates were incubated for 2 days at $30^{\circ} \mathrm{C}$. Afterwards, $5 \mathrm{ml}$ of molten TTC agar seeded with $R$. solanacearum TW 15 was overlain on the second layer using a $5 \mathrm{ml}$ pipette as the third layer. Plates were kept at $30^{\circ} \mathrm{C}$ for 2 days. Thereafter, bacterial colonies showing inhibition zones were purified on TSA medium as suspected antagonists.

Screening of antagonists for effective suppression of R. solanacearum TW1 5

Eighty isolates showing antagonistic activity in the three-layer cultures were screened for effective suppression of the pathogen using perforated agar plate method. Candidate antagonistic bacteria and $R$. solanacearum TW15 were cultivated in King's B broth for $48 \mathrm{hr}$ at $28^{\circ} \mathrm{C}$. One-hundred microliters of $R$. solanacearum TW 15 suspension containing $10^{8} \mathrm{CFU} / \mathrm{ml}$ was spread on King's B plates and holes of $9 \mathrm{~mm}$ diameter punched into the agar. In these holes $50 \mu \mathrm{l}$ suspension of each test antagonist $\left(10^{8} \mathrm{CFU} / \mathrm{ml}\right)$ was added and the plates incubated at $28^{\circ} \mathrm{C}$ for $48 \mathrm{hr}$. Inhibition of $R$. solanacearum TW 15 growth was assessed by measuring the diameter of inhibition zone (mm) after incubation for $48 \mathrm{hr}$ at $28^{\circ} \mathrm{C}$. The most active antagonistic bacteria designated HRA32 and HRA69 were selected and identified by $16 \mathrm{~S}$ rRNA sequencing as described above.

\section{Characterization of antagonists for plant growth promotion (PGP) traits} Siderophore production

Siderophore production was detected by the universal method of Schwyn and Neilands (1987) using blue agar plates containing the dye chrome azurol $\mathrm{S}$ (CAS). Orange halos around the colonies on blue were indicative for siderophore production.

\section{Phosphate Solubilization}

To determine phosphate solubilization qualitatively, Pikovaskya (PKV) agar plates were inoculated with the selected bacterial antagonists. After incubation at $28 \pm 1^{\circ} \mathrm{C}$ for 5 days, the formation of a clear zone around bacterial growth indicating phosphate solubilization capacity as described by Gaur (1990).

\section{$\mathrm{NH}_{3}$ production}

Bacterial isolates were tested for the production of ammonia in peptone water. Freshly grown cultures were inoculated in $10 \mathrm{ml}$ peptone water in each tube and incubated for $48-72 \mathrm{hr}$ at $28 \pm 2{ }^{\circ} \mathrm{C}$. Nessler's reagent $(0.5 \mathrm{ml})$ was 
added in each tube. Development of brown to yellow colour was a positive test for ammonia production (Cappuccino and Sherman, 1992).

\section{Detection of HCN production}

Production of $\mathrm{HCN}$ by bacterial antagonists was observed according to the method of Lorck (1948). Freshly grown cells were spread on King's B or nutrient agar medium containing glycine $(4.5 \mathrm{~g} / \mathrm{l})$. A sterilized filter paper saturated with $1 \%$ solution of picric acid and $2 \%$ sodium carbonate was placed in the upper lid of a petri dish. The petri dish was then sealed with parafilm and incubated at $30^{\circ} \mathrm{C}$ for 4 days. A change in color of the filter paper from yellow to reddish brown indicated $\mathrm{HCN}$ production.

\section{Determination of indole acetic acid (IAA) production}

Quantitative analysis of IAA was performed using the method of Loper and Scroth (1986). Bacterial culture was inoculated in King's B or nutrient broth medium with tryptophan $(1,2$, and $5 \mathrm{mg} / \mathrm{ml})$ or without tryptophan incubated at $28 \pm 2{ }^{\circ} \mathrm{C}$ for one week. Cultures were centrifuged at $3000 \mathrm{rpm}$ for $30 \mathrm{~min}$. Two milliliters of the supernatant was mixed with 2 drops of orthophosphoric acid and $4 \mathrm{ml}$ of Solawaski's reagent $(50 \mathrm{ml}$ of $35 \%$ perchloric acid and $1 \mathrm{ml}$ of $0.5 \mathrm{M}$ $\mathrm{FeCl}_{3}$ ). Development of pink color indicates IAA production. Optical density was measured at 530nm using Jasco spectrophotometer. Concentration of IAA produced by cultures was measured with the help of standard graph of IAA.

Biocontrol activity of the endophytic antagonists against bacterial wilt

Pot Experiments were conducted at Botany and Microbiology Department, Faculty of Science, Cairo University. The two endophytic antagonists HRA23 and HRA69 were evaluated for control of tomato bacterial wilt according method described by Li et al. (2008). Antagonist P. fluorescens HRA32 was cultivated in King's B broth at $28^{\circ} \mathrm{C}$ for $24 \mathrm{hr}$ while B. subtilis strain HRA69 was cultured in $\mathrm{LB}$ broth (trypton $10 \mathrm{~g}$, yeast extract $5 \mathrm{~g}, \mathrm{NaCl} 10 \mathrm{~g}, \mathrm{pH} 7.0 \pm 0.2$ ) at $28^{\circ} \mathrm{C}$ for $24 \mathrm{hr}$. The cells were harvested by centrifugation $(4000 \mathrm{x}, 10 \mathrm{~min})$, washed, and resuspended with sterilised saline $(0.85 \%$ sodium chloride) to the final concentration of $10^{8} \mathrm{CFU} / \mathrm{ml}$. Pathogen $R$. solanacearum TW 15 was grown in casamino acids peptone glucose (CPG) broth (1.0\% peptone, $0.1 \%$ casamino acids, $0.5 \%$ glucose) (Smith et al. 1995) at $28^{\circ} \mathrm{C}$ and $150 \mathrm{rpm}$ on rotary shaker for $48 \mathrm{hr}$; the cells were harvested by centrifuge (4000 $x \mathrm{~g}, 10 \mathrm{~min}$ ), washed and resuspended with sterilised saline until the final concentration of bacteria got $10^{8}$ $\mathrm{CFU} / \mathrm{ml}$.

Tomato seedlings (Solanum lycopersicum) cultivar Castlerock of 21 days old and plastic pots containing a mixture of clay and sand $(1: 1 \mathrm{w} / \mathrm{w}$. Pots were sterilized by autoclaving for $30 \mathrm{~min}$. and each pot was transplanted with one seedling. The experiment included five treatments: (I) HRA32 treatment, plants were treated with antagonis tic endophyte $P$.fluorescens HRA32 and pathogen $R$. solanacearum TW15; (II) treatment HRA69, plants were treated with antagonistic endophyte B. subtilis HR69 and pathogen $R$. solanacearum TW15; 
(III) treatment HRA32/HR69, plants were treated with a mixture of $P$. fluorescens HRA32 and B. subtilis as well as pathogen $R$. solanacearum TW 15; (IV) Control 2, Plants were only inoculated with $R$. solanacearum TW15; and (V) Control 1, plants were treated with the same volume of sterilised saline.

Cultures of antagonistic endophytes were diluted 100 times with sterilised saline to $10^{8} \mathrm{CFU} / \mathrm{ml}$. Plant roots were soaked in HRA32, HRA69 or mixture of their suspension for $20 \mathrm{~min}$. and transplanted immediately; sterilised saline was applied into each control plant and 60 pots were used as replication. At 5 day after transplanting, treatments HRA23, HRA69, HRA32/HR69 and Control 2 were drenched with pathogen $R$. solanacearum TW 15 at $10^{8} \mathrm{CFU} / \mathrm{g}$ soil. The number of wilted plants was recorded in 30 days after transplanting. Disease incidence (DI) was calculated according to Li et al. (2008) with the following formula:

$$
\text { DI }(\%)=\frac{\text { Number of wilted plants in each treatment }}{\text { Total number of plants in each treatment }} \times 100
$$

Biological control efficacy (BCE) was calculated according to Guo et al. (2004) as :

BCE $(\%)=\left[\left(\begin{array}{ll}\mathrm{D}_{\mathrm{C}} & \mathrm{D}_{\mathrm{T}}\end{array}\right) \mathrm{D}_{\mathrm{C}}\right]$, where $\mathrm{D}_{\mathrm{C}}$ is disease incidence of control 2 and $\mathrm{D}_{\mathrm{T}}$ is disease incidence of the treatment group.

\section{Statistical analysis}

The measured data were subjected to the analysis of variance (ANOVA) appropriate to the design. The significant differences between treatments were compared with the critical difference at $5 \%$ level of probability by the Duncan's test using PASW 17.0 statistics software (SPSS Inc).

\section{Results and Discussion}

\section{Isolation and identification of Ralstonia solanacearum}

It was found that stem pieces of wilted tomato plants when dipped in water showed a continuous white streaming of bacterial ooze. From this suspension bacterial colonies were isolated on TTC agar. After $48 \mathrm{hr}$ of incubation at $30^{\circ} \mathrm{C}$, viscous colonies with pink centre and white border developed on the plate were picked. KOH soluble colony designated TW15 was selected and its 16S rRNA gene was amplified by PCR. The amplicon was purified and sequenced and the obtained sequence $(1,401 \mathrm{bp}$ ) was submitted to the GenBank database under the accession number KU132386. BLASTn analysis of the 16S rRNA sequence revealed that it was phylogenetically clustered with $R$. solanacearum showing $100 \%$ similarity to $R$. solanacearum UQRS 652 (accession number KC757033.1) and $R$. solanacearum ISPaVe 1322 (accession number AM690478.1). These results are in close agreement with the EzTaxon results. The results of biovar test revealed that $R$. solanacearum TW 15 had positive response for lactose, maltose and cellobiose and negative results were observed for mannitol, sorbitol and dulcitol. Based on these results, R. solanacearum TW 15 was classified as biovar 2 .

Egypt. J. Bot., 56, No. 2 (2016) 
Isolation, screening and identification of antagonistic endophytes

For isolation of potential antagonistic endophytes that suppress $R$. solanacearum TW15, modified triple layer agar technique and perforated agar method were used. Of 80 screened potential antagonistic isolates, two isolates designated HRA32 and HRA69 showing the largest inhibition zones were selected for identification and further studies (Fig. 1).

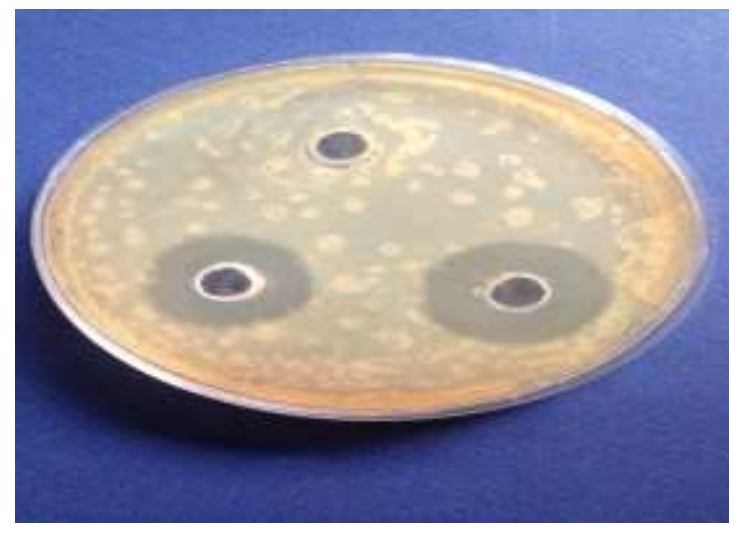

Fig. 1. Screening antagonistic activity of endophytic isolates against $R$. solanacearum by perforated agar method.

The most efficient antagonistic endophytes HRA32 and HRA69 were subjected to identification by amplification and sequencing their 16S rRNA gene. Based on BLASTn analysis and EzTaxon-e server database results, HRA32 and HRA69 were identified as Pseudomonas fluorescens and Bacillus subtilis, respectively. 16S rRNA sequence of $P$. fluorescens HRA32 and $B$. subtilis HRA69 were submitted to GenBank database under the accession numbers KU132384 and KU132385, respectively.

\section{Characterization of antagonistic endophytes for PGP traits}

\section{Siderophore production}

Siderophores production assay was conducted on the Chrome azurol S agar medium. The two bacterial species ( $P$. fluorescens HRA32 and B. subtilis HRA69) produced siderophore that indicated by formation of yellow-orange halo around the bacterial growth due to iron chelation by siderophore production as shown in Fig. 2. These results were agreed with several authors who documented siderophore production by Pseudomonas spp (Hammami et al. 2013; Dharni et al., 2014 and Gusain et al., 2015). In addition, siderophore production by Bacillus spp was described as an important trait in growth promotion and suppression of phytopathogens (Colo et al., 2014 and Das et al., 2014; Haiyambo et al., 2015 and Sunar et al., 2015). Siderophores are lowmolecular-weight molecules that are secreted by many microorganisms in iron limiting conditions (Crowley et al., 1991). There are several reports that showed microbial siderophores have a positive correlation with plant growth promotion 
and biocontrol efficacy; therfore production of siderophores is one of the key factors that should be considered in PGPR screening programs (Chaiharn et al., 2009 and Sulochana et al., 2014).

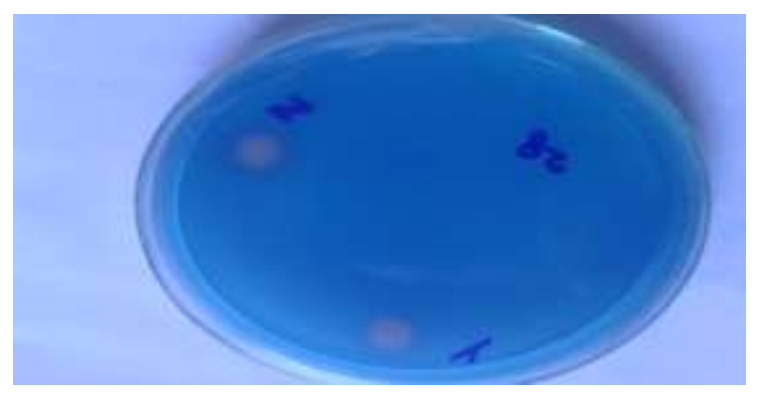

Fig. 2. Siderophore production by endophytic antagonists.

\section{Phosphate solubilization}

The ability of $P$. fluorescens HRA32 and B. subtilis HRA69 to solubilize inorganic phosphate was performed on Pikovaskya (PKV) agar plates qualitatively. Results revealed that both investigated isolates had the ability to solubilize inorganic phosphate efficiently. However B. subtilis HRA69 was more active in phosphate solubilization compared to P. fluorescens HRA32 (Fig. 3). Phosphate solubilizing bacteria increase availability of phosphorus to plants by solubilization of insoluble phosphorus in soil into soluble forms available for plant growth hence they act as biofertilizers. Phosphate is often the limiting nutrient for microbial and plant growth in soil and it is believed that solubilization of insoluble $\mathrm{P}$ from rock phosphate is due to the excretion of microbial metabolites such as organic acids (Gyaneshwar et al., 1998; Carrillo et al., 2002 and Rodriguez et al., 2004). Many reports recorded plant yield increases due to phosphate solubilizing bacteria in different crops (Afzal et al., 2005; Naik et al., 2008; Saïdi et al., 2013 and Shi et al., 2014).

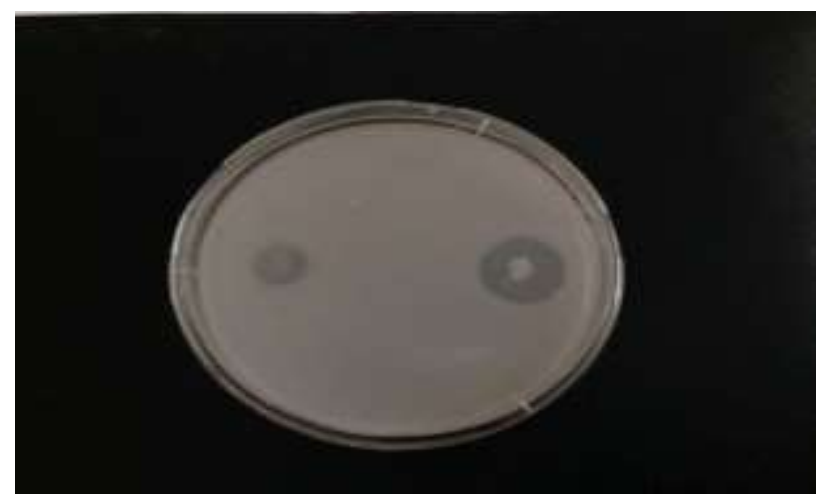

Fig. 3. Phosphate solubilization by endophytic antagonists.

Egypt. J. Bot., 56, No. 2 (2016) 


\section{$\mathrm{NH}_{3}$ production}

The production of ammonia was investigated in peptone water. Both $P$. fluorescens HRA32 and B. subtilis HRA69 were positive for ammonia production (Table 1). It was suggested that produced ammonia increases available nitrogen in soil and may has a positive effect on plant growth. In accordance with these findings Ahmed et al. (2008) screened 72 isolates of plant growth promoting rhizobacteria and found that all assessed fluorescent pseudomonads isolates were able to produce ammonia. Similar results were obtained by Anitha and Kumudini (2014).

TABLE 1. Characterization of selected bacterial isolates for plant growth promoting traits

\begin{tabular}{|c|c|c|}
\hline \multirow{2}{*}{ Characteristics } & \multicolumn{2}{|c|}{ Bacterial isolate } \\
\cline { 2 - 3 } & P. fluorescens HRA32 & B. subtilis HRA69 \\
\hline Siderophore production & + & + \\
\hline Phosphate Solubilization & + & + \\
\hline $\mathrm{NH}_{3}$ production & + & + \\
\hline HCN production & + & - \\
\hline
\end{tabular}

Detection of HCN production : Production of $\mathrm{HCN}$ by bacterial is olates was tested. For the two bacterial isolates, only P. fluorescens HRA32 showed a positive result that observed by changing the color of the filter paper from yellow to reddish brown indicating $\mathrm{HCN}$ production (Table 1). The cyanide ion derived from $\mathrm{HCN}$ is a potent inhibitor of many metalloenzymes, especially copper containing cytochrome $c$ oxidases (Blumer and Haas, 2000). In a previous study, HCN production by Pseudomonas sp was reported as important factor for control of bacterial canker disease of tomato caused by Clavibacter michiganensis subsp. Michiganensis (Lanteigne et al., 2012).

Determination of IAA production : Quantitative analysis of IAA was performed using King's B broth and nutrient broth medium with tryptophan (1,2 and $5 \mathrm{mg} / \mathrm{ml}$ ) or without tryptophan. Results revealed that $P$. fluorescens HRA32 was able to produce IAA without tryptophan, while IAA production by $B$. subtilis HRA69 was tryptophan-dependent. A significant increase in the production of IAA was observed in the presence of increased concentrations of tryptophan (1,2 and $5 \mathrm{mg} / \mathrm{ml}$ ) (Table 2). These findings were in close agreement with those reported in various studies dealing with IAA production by rhizobacteria showing significant enhancement of IAA by corporation of tryptophan into culture medium (Baldan et al., 2015 ;Sauvêtre and Schröder, 2015). Tryptophan and indole-3-acetamides are the key intermediates in the IAA biosynthesis pathways (Barbieri and Galli, 1993; Patten and Glick, 2002). Auxin may increase plant growth through cell enlargement, cell division, root initiation, increased growth rate and apical dominance (Frankenberger and Arshad 1995). 
TABLE 2. Production of IAA by the two antagonistic endophytes.

\begin{tabular}{|c|c|c|}
\hline \multirow{2}{*}{$\begin{array}{c}\text { Tryptophan } \\
\text { concentration }(\mathbf{m g} / \mathbf{m l})\end{array}$} & \multicolumn{2}{|c|}{ Procuction of IAA $(\boldsymbol{\mu g} / \mathbf{m l})$} \\
\cline { 2 - 3 } & P. fluorescens HRA32 & B. subtilis HRA69 \\
\hline 0 & 3.12 & - \\
\hline 1 & 12.56 & 23.17 \\
\hline 2 & 28.46 & 33.22 \\
\hline 5 & 48.39 & 59.66 \\
\hline
\end{tabular}

Evaluation of endophytic antagonists for bacterial wilt biocontrol

In vivo evaluations were conducted to assess the screened antagonists using tomato seedlings. All tested bio-control agents caused a significant reduction of wilt disease compared to the control (Table $3 \&$ Fig. 4). Results indicated that $P$. fluorescens HRA32 was more efficient in controlling bacterial wilt disease compared to B. subtilis HRA69. Trials with $P$. fluorescens HRA32 and $B$. subtilis HRA69 as separate treatments had disease incidence of $30.83 \%$ and $43.13 \%$, respectively. Clear synergetic effect was observed when P. fluorescens HRA32 and B. subtilis HRA69 were applied together as a mixture causing the lowest disease incidence $(16.66 \%)$. Biological control efficacy of P. fluorescens HRA32 and B. subtilis HRA69 was $63.24 \%$ and $48.41 \%$, respectively, whereas its maximum value $(80.23 \%)$ was achieved by using a mixture of them. These results agreed with those obtained by Li et al. (2008) who reported the use of efficient biocontrol agent $B$. subtilis strain AR12 that showed high biocontrol efficiency $(90.18 \%)$ against bacteria wilt of tomato. In a similar study, Pseudomonas aeruginosa T1, Pseudomonas sp. BH25, Pseudomonas sp. AM12, Pseudomonas sp. AM13 and Pseudomonas putida R6 were reported as potent agents in control bacterial wilt in tomato (Maji and Chakrabartty, 2014).

TABLE 3. Efficacy of antagonistic endophytes in controlling tomato bacterial wilt.

\begin{tabular}{|c|c|c|}
\hline Treatment & $\begin{array}{c}\text { Disease incidence } \\
(\boldsymbol{\%})\end{array}$ & $\begin{array}{c}\text { Biological control efficacy } \\
(\boldsymbol{\%})\end{array}$ \\
\hline Control 1 & 0 & -------- \\
\hline Control 2 & $87.22 \pm 4.19^{(\mathrm{a})}$ & ------- \\
\hline HRA32 & $30.83 \pm 3.53^{\text {(c) }}$ & $63.24 \pm 5.74^{(\mathrm{b})}$ \\
\hline HRA69 & $43.133 \pm 2.30^{\text {(b) }}$ & $48.41 \pm 4.96^{\text {(c) }}$ \\
\hline HRA32/HRA69 & $16.66 \pm 2.35^{\text {(d) }}$ & $80.23 \pm 1.97^{\text {(a) }}$ \\
\hline
\end{tabular}

The same letter in each column indicates no significant difference according to Duncan's multiple range test $(\mathrm{p}<0.05)$.

$( \pm)$ represent standard deviations (SD). 


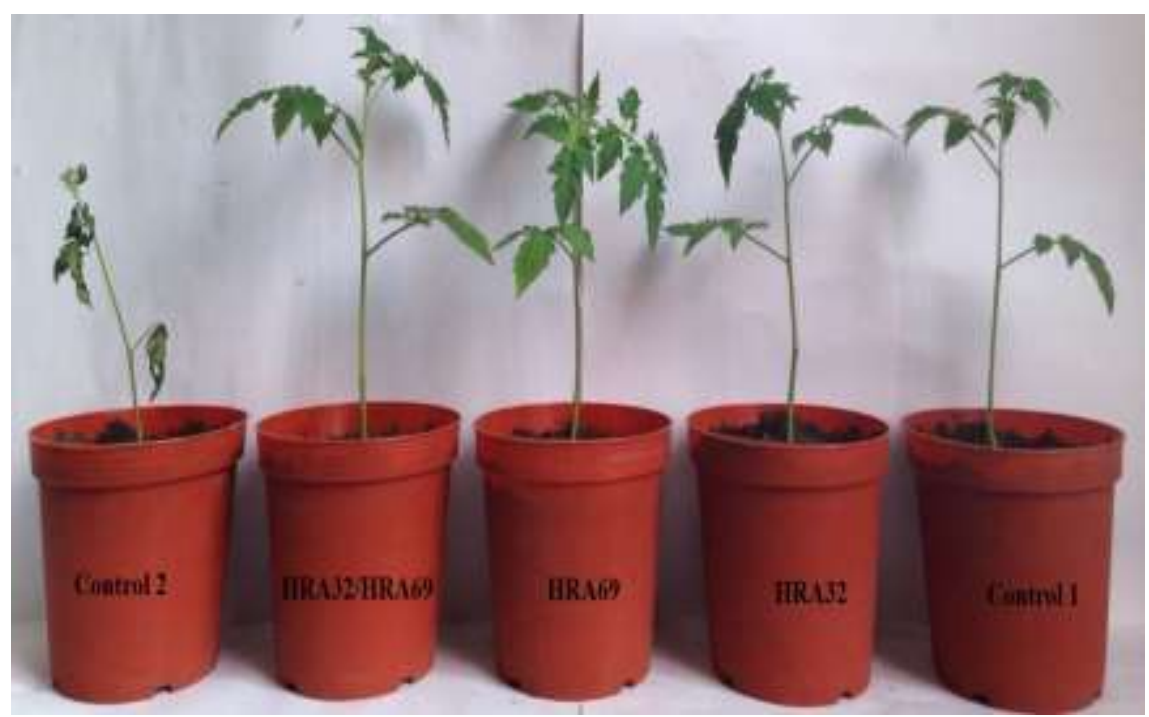

Fig. 4. Efficacy of antagonistic endophytes in controlling tomato bacterial wilt.

HRA32: plants were treated with antagonistic endophyte $P$. fluorescens HRA32 and pathogen $R$. solanacearum TW15; HRA69: plants were treated with antagonistic endophyte $B$. subtilis HR69 and pathogen $R$. solanacearum TW15; HRA32/HR69: plants were treated with a mixture of $P$. fluorescens HRA32 and $B$. subtilis as well as pathogen $R$. solanacearum TW15; Control 2: Plants were only inoculated with $R$. solanacearum TW15; Control 1: plants were treated with the same volume of sterilised saline.

\section{References}

Afzal, A., Ashraf, M., Asad, S.A. and Farooq, M. (2005) Effect of phosphate solubilizing microorganisms on phosphorus uptake, yield and yield traits of wheat (Triticum aestivum L.) in rainfed area. Int. J. Agric. Biol., 7, 207-209.

Ahmed, F., Ahmad, I. and Khan, M.S. (2008) Screening of free-living rhizospheric bacteria for their multiple plant growth promoting activities. Microbiological Research, 163, 173-181.

Anitha, G. and Kumudini, B.S. (2014) Isolation and characterization of fluorescent pseudomonads and their effect on plant growth promotion. J. Environ Biol., 35, 627-634.

Babu, A.N., Jogaia, H., Ito, S., Nagaraj, A.K. and Tran, L.P. (2015) Improvement of growth, fruit weight and early blight disease protection of tomato plants by rhizosphere bacteria is correlated with their beneficial traits and induced biosynthesis of antioxidant peroxidase and poly phenol oxidase. Plant Science, 231, 62-73.

Barbieri, P. and Galli, E. (1993) Effect of wheat root development of inoculation with an Azospirillum brasilense mutant with altered indole-3-acetic acid production. Res. Microbiol., 144, 69-75. 
Baldan, E., Nigris, S., Romualdi, C., D'Alessandro, S., Clocchiatti, A., Zottini, M., Stevanato, P., Squartini, A. and Baldan B. (2015) Beneficial Bacteria Isolated from Grapevine Inner Tissues Shape Arabidopsis thaliana Roots. PLoS One. 10, 10.

Blumer, C. and Haas, D. (2000) Mechanism, regulation, and ecological role of bacterial cy anide biosy nthesis. Arch. Microbiol., 173, 170-177.

Cappuccino, J.C. and Sherman, N. (1992) In: "Microbiology: A Laboratory Manual", $3^{\text {rd }}$ ed. Benjamin/cummings Pub. Co., New York, pp. 125-179.

Carrillo, A.E, Li, C.Y. and Bashan, Y. (2002) Increased acidification in the rhizosphere of cactus seedlings induced by Azospirillum brasilense. Naturwissenschaften, 89, 428-432.

Chaiharn, M., Chunhaleuchanon, S. and Lumyong, S. (2009) Screening siderophore producing bacteria as potential biological control agent for fungal rice pathogens in Thailand. World Journal of Microbiology and Biotechnology, 25, 1919-1928.

Colo, J., Hainal-Jafari, T.I., Durić, S., Stamenov, D. and Hamidović, S. (2014) Plant growth promotion rhizobacteria in onion production. Pol. J. Microbiol., 63, 83-88.

Crowley, D.E., Wang, Y.C., Reid, C.P.P. and Szaniszlo, P.J. (1991) Mechanisms of iron acquisition from siderophores by microorganisms and plants. Plant Soil, 130, 179-198.

Das, S., Jean, J.S., Kar, S., Chou, M.L. and Chen, C.Y. (2014) Screening of plant growth-promoting traits in arsenic-resistant bacteria isolated from agricultural soil and their potential implication for arsenic bioremediation. J. Hazard Mater, 272, 112-120.

Dharni, S., S rivastava, A.K., S amad, A. and Patra, D.D. (2014) Impact of plant growth promoting Pseudomonas monteilii PsF84 and Pseudomonas plecoglossicida PsF610 on metal untake and production of secondarv metabolite (monoterpenes) bv rosescented geranium (Pelargonium graveolens cv. bourbon) grown on tannery sludge amended soil. Chemosphere, 117, 433-439.

Food and Agriculture Organization of United Nations, Agriculture Data FAO (2010) http://www.foa.org.

Frankenberger, W.T. and Arshad, M. (1995) Auxins, In : "Phytohormones in Soils: Microbial Production and Function". W.T. Frankenberger and M. Arshad (Ed.), Marcel Dekker, Inc., New York, N.Y. pp. 17-136.

Gaur, A.C. (1990) Physiological functions of phosphate solubilizing micro-organisms. In: "Phosphate Solubilizing Micro-organisms as Biofertilizers". Gaur, A.C. (Ed.), Omega Scientific Publishers, New Delhi, pp. 16-72.

Grimault, V., Anais, G. and Prior, P. (1994) Distribution of Pseudomonas solanacearum in the stem tissues of tomato plants with different levels of resistance to bacterial wilt. Plant Pathology, 43, 663-668.

Guo, J.H., Qi, H.Y., Guo, Y.H., Ge, H., Gong, L.Y., Zhang, L.X. and Sun, P.H. (2004) Biocontrol of tomato wilt by growth-promoting rhizobacteria. Biol. Control, 29, 66-72.

Egypt. J. Bot., 56, No. 2 (2016) 
Gusain, Y.S., Kamal, R., Mehta, C.M., Singh, U.S. and Sharma, A.K. (2015) Phosphate solubilizing and indole-3-acetic acid producing bacteria from the soil of Garhwal Himalay a aimed to improve the growth of rice. J. Environ Biol., 36, 301-307.

Gyaneshwar, P., Kumar, G.N. and Parekh, L.J. (1998) Effect of buffering on the phosphate-solubilizing ability of microorganisms. W. J. Microbiol Biotechnol., 14, 669-673.

Haivambo. D.H.. Chimwamurombe. P.M. and Reinhold-Hurek. B. (2015) Isolation and screening of rhizosphere bacteria from grasses in east kavango region of namibia for plant growth promoting characteristics. Curr Microbiol., 71, 566-571.

Hammami, I., Ben Hsouna, A., Hamdi, N., Gdoura, R. and Triki, M.A. (2013) Isolation and characterization of rhizosphere bacteria for the biocontrol of the damping-off disease of tomatoes in Tunisia. C. R. Biol., 336, 557-564.

Hayward, A.C. (1964) Characteristics of Pseudomonas solanacearum. J. Appl. Bacteriol., 27, 265-277.

Herr, J.L. (1959) A method of assaying soils for numbers of actinomycetes antagonistic to fungal pathogens. Phytopathology, 49. 270-273.

Jha, C.K., Annapurna, K. and Saraf, M. (2012) Isolation of Rhizobacteria from Jatropha curcas and characterization of produced ACC deaminase. J. Basic. Microbiol., 52, 285-295.

Ji, P., Momol, M.T., Olson, S.M., Pradhanang, P.M. and Jones, J.B. (2005) Evolution of thymol as biofunmigant for control of bacterial wilt of tomato under field conditions. Plant Dis., 89, 497-500.

Kelman, A. (1954) The relationship of pathogenicity in Pseudomonas solanacearum to colony appearance on a tetrazolium medium. Phytopathology, 44, 693-695.

Kim, O.S., Cho, Y.J., Lee, K., Yoon, S.H., Kim, M., Na, H., Park, S.C., Jeon, Y.S., Lee, J.H., Yi, H., Won, S. and Chun, J. (2012) Introducing EzTaxon-e: a prokaryotic 16S rRNA gene sequence database with phylotypes that represent uncultured species. International Journal of Systematic and Evolutionary Microbiology, 62, 716-721.

Lanteigne, C., Gadkar, V.J., Wallon, T., Novinscak, A. and Filion, M. (2012) Production of DAPG and HCN by Pseudomonas sp. LBUM 300 contributes to the biological control of bacterial canker of tomato. Phytopathology. 102, 967-973.

Lemessa. F. and Zeller. W. (2007) Screening rhizobacteria for biological control of Ralstonia solanacearum in Ethiopia. Biological Control, 42, 336-344.

Li, S.M., Hua, G.G., Liu, H.X. and Guo, J.H. (2008) Analy sis of defence enzymes induced by antagonistic bacterium Bacillus subtilis strain AR12 towards Ralstonia solanacearum in tomato. Ann. Microbiol., 58, 573-578.

Loper, J.E. and Scroth, M.N. (1986) Influence of bacterial sources on indole-3 acetic acid on root elongation of sugar beet. Phytopathology, 76, 386-389.

Egypt. J. Bot., 56, No.2 (2016) 
Lorck, H. (1948) Production of hydrocy anic acid by bacteria. Physiol Plant , 1, 142-146.

Lugtenberg, B. and Kamilova, F. (2009) Plant-growth-promoting rhizobacteria. Аnnu. Rev. Microbiol., 63, 541-556.

Maji, S . and Chakrabartty, P.K. (2014) Biocontrol of bacterial wilt of tomato caused by Ralstonia solanacearum by isolates of plant growth promoting rhizobacteria. Australian Journal of Crop Science, 8, 208-214.

Mansotra, P., Sharma, P. and Sharma, S. (2015) Bioaugmentation of Mesorhizobium cicer, Pseudomonas spp. and Piriformospora indica for sustainable chickpea production. Physiol. Mol. Biol. Plants, 21, 385-393.

Naik, P.R, Narayanum, K.B, Raman, G. and Sakthivel, N. (2008) Assessment of genetic and functional diversity of phosphate solubilizing fluorescent Pseudomonas isolated from rhizospheric soil. BMC Microbiol., 8, 230-235.

Nguyen, M.T. and Ranamukhaarachchi, S.L. (2010) Soil-Borne antagonists for biological control of bacterial wilt disease caused by Ralstonia solanacearum in tomato and pepper. Journal of Plant Pathology, 92, 395-406.

Patten, C.L. and Glick, B.R. (2002) Role of Pseudomonas putida indole-acetic acid in development of the host plant root system. Appl. Environ. Microbiol., 68, 3795-3801.

Rodriguez, H., Gonzalez, T., Goire, I. and Bashan, Y. (2004) Gluconic acid production and phosphate solubilization by the plant growth promoting bacterium Azospirillum spp. Naturwissenschaften, 91, 552-555.

Saïdi, S., Chebil, S., Gtari, M. and Mhamdi, R. (2013) Characterization of root-nodule bacteria isolated from Vicia faba and selection of plant growth promoting isolates. World J. Microbiol Biotechnol., 29, 1099-1106.

Saile, E., McGarvey, J., Schell, M. and Denny, T. (1997) Role of extracellular polysaccharide and endoglucanase in root invasion and colonization of tomato plants by Rastonia solanacearum. Phytopathology, 87, 1264-1271.

Sauvêtre, A. and Schröder, P. (2015) Uptake of carbamazepine by rhizomes and endophytic bacteria of Phragmites australis. Front Plant Sci., 6, 83.

Schaad, N.W. (1988) Evaluation of an avirulent strain of Pseudomonas solanacearum for biological control of bacterial wilt of potato. American Potato Journal, 65, 255-268.

Schwyn, B. and Neilands, J.B. (1987) Universal chemical assay for the detection and determination of siderophores. Anal. Biochem. 160, 47-56.

Seleim, M.A., Abo-Elyousr, K.A., Abd-El-Moneem, K.M. and Saead, F.A. (2014) First report of bacterial wilt caused by Ralstonia solanacearum biovar 2 race 1 on tomato in Egy pt. Plant Pathol. J., 30, 299-303.

Shi, F., Yin, Z., Jiang, H. and Fan, B. (2014) Screening, identification of P-dissolving fungus P83 strain and its effects on phosphate solubilization and plant growth promotion. Wei Sheng Wu Xue Ba., 54, 1333-1343.

Egypt. J. Bot., 56, No. 2 (2016) 
Smith, J.J., Offord, L.C., Holderness, M. and Saddler, G.S. (1995) Genetic diversity of Burkholderia solanacearum (Synonym Pseudomonas solanacearum) race 3 in Kenya. Appl. Environ. Microbiol., 61, 4263-4268.

Sulochana, M.B., Jayachandra, S.Y., Kumar, S.A., Parameshwar, A.B., Reddy, K.M. and Dayanand, A. (2014) Siderophore as a potential plant growth-promoting agent produced by Pseudomonas aeruginosa JAS-25. Appl Biochem Biotechnol., 174, $297-$ 308.

Sunar, K., Dey, P., Chakraborty, U. and Chakraborty, B. (2015) Biocontrol efficacy and plant growth promoting activity of Bacillus altitudinis isolated from Darjeeling hills, India. J. Basic Microbiol., 55, 91-104.

S wanson, J.K., Yao, J., Tans-Kersten, J. and Allen, C. (2005) Behavior of Ralstonia solanacearum race 3 biovar 2 during latent and active infection of geranium. Phytopathololy, 95, 136-143.

Thokchom, E., Kalita, M.C. and Talukdar, N.C. (2014) Isolation, screening, characterization. and selection of superior rhizobacterial strains as bioinoculants for seedling emergence and growth promotion of Mandarin orange (Citrus reticulata Blanco). Can. J. Microbiol., 60, 85-92.

Vasse, J., Frey, P. and Trigalet, A. (1995) Microscopic studies of intercellular infection and protoxylem invasion of tomato roots by Pseudomonas solanacearum. Mol. PlantMicrobe. Interact. 8, 241-251.

Wang, Y., Li, H., Zhao, W., He, X., Chen, J., Geng, X. and Xiao, M. (2010) Induction of toluene degradation and growth promotion in corn and wheat by horizontal gene transfer within endophy tic bacteria. Soil Biol Biochem., 42, 1051-1057.

Williamson, L., Nakaho,K., Hudelson, B. and Allen, C. (2002) Ralstonia solanacearum race 3, biovar 2 strains isolated from geranium are pathogenic on potato. Plant Dis., 86, 987-991.

(Received 6/12/2015;

accepted 5/1/2016) 


$$
\begin{aligned}
& \text { السيطرة البيولوجية لمرض الذبول البكتيري في الطماطم بواسطة } \\
& \text { بعض أنواع البكتريا الداخلية الجذرية البرلية }
\end{aligned}
$$

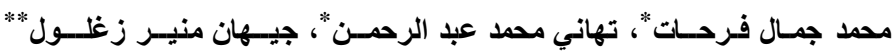

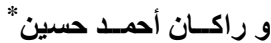

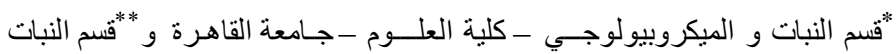

$$
\begin{aligned}
& \text { و الميكروبيولوجي - كلية العلوم - جامعة حلوان - مصر. }
\end{aligned}
$$

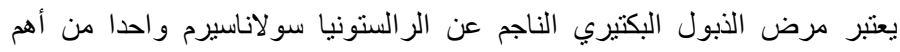

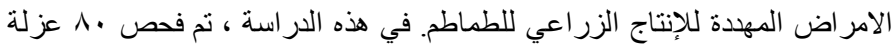

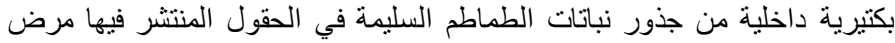

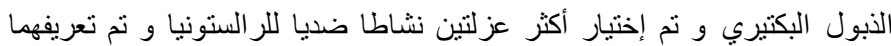

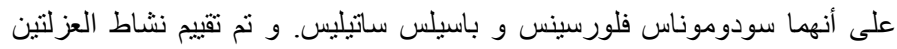

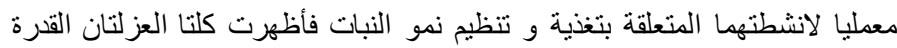

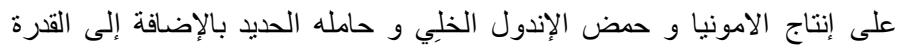

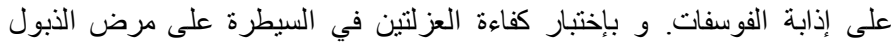

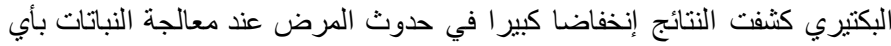

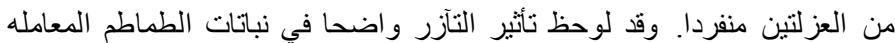

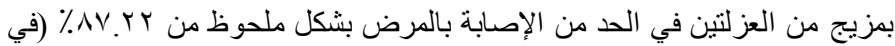

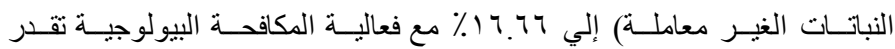

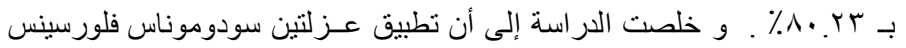

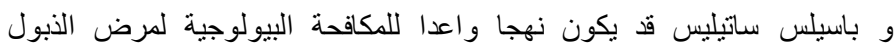

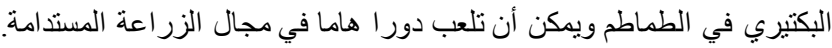

